\title{
Endogenous nitrogen metabolism and plasma free amino acids in young adults given a 'protein-free' diet*
}

\author{
By V. R. YOUNG AND N. S. SCRIMSHAW \\ Department of Nutrition and Food Science, Massachusetts Institute \\ of Technology, Cambridge, Massachusetts 02139, USA
}

(Received 7 February 1967-Accepted 25 Fuly 1967)

\begin{abstract}
1. Variation in endogenous nitrogen metabolism was determined by giving eleven healthy men, aged $\mathrm{r}^{-222}$, a diet supplying daily only $6 \mathrm{mg} \mathrm{N} / \mathrm{kg}$ body-weight. Eight subjects were given the diet for 7-ro days and three other subjects were given it for 16 days.

2. Body cell mass (BCM) was calculated from whole-body ${ }^{40} \mathrm{~K}$ in ten subjects and basal metabolism was determined in seven subjects during the 'protein-free' period. Urine was analysed daily for $\mathrm{N}$ and creatinine, and faecal $\mathrm{N}$ was measured in pooled samples. Plasma free amino acids, serum albumin and protein were measured in preprandial morning blood samples at the beginning and end of the study.

3. BCM did not change during the 'protein-free' period and accounted for $48 \%$ of the total body-weight. Basal calorie expenditure amounted to $48 \cdot 5 \mathrm{kcal} / \mathrm{kg} \mathrm{BCM}$ per day.

4. Mean daily endogenous urinary $\mathrm{N}$ excretion in the eight subjects given the "protein-

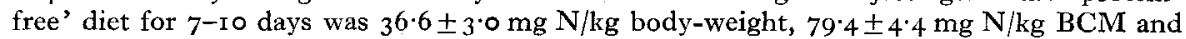
$\mathrm{I} \cdot 6 \pm 0.2 \mathrm{mg} \mathrm{N} /$ basal kcal. Endogenous faecal $\mathrm{N}$ excretion was $9 \cdot 9 \pm \mathrm{I} \cdot \mathrm{I} \mathrm{mg} \mathrm{N} / \mathrm{kg}$ bodyweight and accounted for $20 \%$ of the total endogenous loss. Results obtained with three other subjects given the diet for 16 days were similar.

5. Plasma essential amino acids were reduced, glutamic acid, alanine and glycine increased, and the ratio of essential to non-essential amino acids decreased after 7 or Io days of "proteinfree' diet.

6. The loss of endogenous $\mathrm{N}$ per basal kcal and of faecal $\mathrm{N}$ per $\mathrm{kg}$ body-weight was lower than the values assumed in the factorial approach to protein requirements by the FAO/WHO (1965) Expert Group on Protein Requirements.
\end{abstract}

The two major components of man's protein requirements are: (I) the amount and relative proportions of essential amino acids, and (2) the quantity of nitrogen required for the synthesis of non-essential amino acids and other $\mathrm{N}$-containing compounds. The requirements for essential amino acids have been determined in men and women having relatively high intakes of total $\mathrm{N}$ (Rose, I957; Leverton, Ellison, Johnson, Pazur, Schmidt \& Geschwender, I956; Swendseid \& Dunn, 1956), and the results suggest wide individual variation in the requirements for certain of the essential amino acids.

The need for lysine and the branched-chain amino acids varied among subjects by as much as two- to three-fold (Rose, I957; Leverton et al. 1956). A number of factors may account for this finding. The efficiency of absorption and subsequent utilization of the amino acids may vary (Scrimshaw, 1962-3). Studies in both experimental animals (Harper, 1964) and human subjects (Scrimshaw, Bressani, Béhar \& Viteri, I958; Clark, Myers, Groyal \& Rinehart, 1966) show clearly that the requirement for a particular amino acid is influenced by the relative proportions of other

* This manuscript is contribution no. I035 from the Department of Nutrition and Food Science, Massachusetts Institute of Technology, Cambridge, Mass. 
acids present in the diet. Furthermore, the utilization of the essential amino acids is influenced by the total amount of $\mathrm{N}$ in the diet (Kies, Shortridge \& Reynolds, I965; Tuttle, Swendseid, Mulcare, Griffith \& Bassett, 1959; Clark, Kenney, Goodwin, Goyal \& Mertz, 1963), which in turn may accentuate variability among subjects.

Recent investigations conducted in our laboratory (Scrimshaw, Young, Schwartz, Piché \& Das, I966; Huang, Young, Cholakos \& Scrimshaw, 1966) have been concerned with determining the minimum proportion of essential amino acids to total dietary $\mathrm{N}$ necessary for adequate protein nutrition in young adult subjects. Using whole-egg protein, which presumably has an ideal balance of essential amino acids (FAO/WHO, I965), as the major protein component of the diet, we have noted a wide variation in the metabolic response of subjects to an isonitrogenous replacement of protein with a non-specific $\mathrm{N}$ source (Scrimshaw et al. 1966). Our results were obtained at relatively low levels of $\mathrm{N}$ intake, and we have examined the extent to which variations in endogenous $\mathrm{N}$ excretion may reflect the variability in amino acid requirements. The results obtained with eleven subjects given a 'protein-free' diet for $7^{-16}$ days form the basis of this report. Because of limited information about the excretion of endogenous $\mathrm{N}$ per unit of basal-energy expenditure in young adults (Murlin, Edwards, Hawley \& Clark, 1946a; Deuel, Sandiford, Sandiford \& Boothby, 1928; Smith, 1926; Bricker \& Smith, I95I), we have, during these studies, also measured basal metabolism and examined the relationship between endogenous $\mathrm{N}$ excretion and body cell mass (BCM), calculated from whole-body ${ }^{40} \mathrm{~K}$ content.

Although a number of studies have been concerned with the influence of lowprotein diets on plasma amino acids (Swendseid, Tuttle, Figueroa, Mulcare, Clark \& Massey, I 966), there appears to be a need for information on the influence of a ' proteinfree' diet on plasma amino acid levels in healthy adults. This report also describes preprandial plasma amino acid levels in healthy, young adult males receiving 'proteinfree' diets.

\section{EXPERIMENTAL}

The age, weight, height, protein intake before the experiment and calorie intake, calculated from food composition tables (Watt \& Merril, r963) and data supplied by the manufacturers of some of the dietary components, for the eleven subjects studied are given in Table I. All were in good health as judged by medical histories and physical examinations at the beginning and the end of the experiments. The studies were conducted in the M.I.T. Clinical Research Centre, and the subjects were maintained under close nursing and medical supervision. They were required to continue their usual levels of physical activity throughout the study.

All subjects received adequate protein for at least a week before the 'protein-free' period (Table I). The composition of the 'protein-free' diet is given in Table 2. It was found necessary to include a small amount of oatmeal in the fluid mixture to maintain a stable mixture of agreeable consistency. The diet supplied only $6 \mathrm{mg} \mathrm{N} / \mathrm{kg}$ day and was therefore, designated as 'protein-free'. We have used this designation for the diet throughout the remainder of this paper. 
Table I. Age, weight, height and calculated calorie intake of young men given a 'proteinfree' diet for periods of 7-16 days

\begin{tabular}{|c|c|c|c|c|c|c|}
\hline \multirow[b]{2}{*}{ Subject } & \multirow[b]{2}{*}{$\begin{array}{c}\text { Age } \\
\text { (years) }\end{array}$} & \multirow[b]{2}{*}{$\begin{array}{l}\text { Body-wt } \\
\quad(\mathrm{kg})\end{array}$} & \multirow[b]{2}{*}{$\begin{array}{l}\text { Height } \\
(\mathrm{cm})\end{array}$} & \multirow{2}{*}{$\begin{array}{l}\text { Calculated } \\
\text { calorie } \\
\text { intake } \\
\text { (kcal/kg } \\
\text { body-wt) }\end{array}$} & \multicolumn{2}{|c|}{$\begin{array}{l}\text { Protein intake before } \\
\text { 'protein-free' period* }\end{array}$} \\
\hline & & & & & $\begin{array}{c}\mathrm{g} / \mathrm{kg} \\
\text { body-wt } \\
\text { day }\end{array}$ & $\begin{array}{l}\text { No. of } \\
\text { days } \\
\text { given }\end{array}$ \\
\hline M.R. & 18 & $75 \cdot 8$ & 183 & 35 & 0.8 & 7 \\
\hline I.J. & 22 & $79 \cdot 9$ & 191 & 37 & 0.8 & 7 \\
\hline J.S. & 18 & $67 \cdot 5$ & 175 & 40 & 0.8 & 7 \\
\hline G.C. & I 8 & $64 \cdot 5$ & I 78 & 48 & $I \cdot 0$ & 7 \\
\hline W.S. & I9 & $64 \cdot 8$ & I 68 & 40 & $I \cdot 0$ & 7 \\
\hline J.G. & 20 & $67 \cdot 7$ & 170 & 42 & $I \cdot 0$ & 7 \\
\hline N.M. & 17 & $72 \cdot 7$ & 174 & 38 & 0.8 & 14 \\
\hline B.R. & 19 & $67 \cdot 4$ & 178 & 43 & 0.8 & 14 \\
\hline D.P. & I8 & 66.9 & 178 & 43 & 0.8 & 14 \\
\hline R.W. & 18 & $70 \%$ & I 55 & 33 & 1.0 & 14 \\
\hline P.S. & 22 & $86 \cdot 8$ & 188 & 36 & $I \cdot 3$ & 30 \\
\hline
\end{tabular}

'Table 2. Composition of fluid 'protein-free' and maintenance protein diets used during the experimental periods

\begin{tabular}{|c|c|c|c|c|}
\hline & $'$ Pro & -free' & Mai & ance \\
\hline & $\mathrm{g} / 100 \mathrm{~g}$ & g/day* & $\mathrm{g} / 100 \mathrm{~g}$ & g/day* \\
\hline Whole dried egg $\dagger$ & - & - & $4 \cdot 4$ & 49 \\
\hline Oatmealf & $12 \cdot 6$ & 119 & $6 \cdot 1$ & 68 \\
\hline Dexin§ & $26 \cdot 5$ & 250 & $17 \cdot 4$ & I94 \\
\hline Maize oil & $12 \cdot 2$ & I 15 & $8 \cdot 8$ & 98 \\
\hline Glucose & - & - & 0.4 & 4.5 \\
\hline Lemon juice & $2 \cdot 5$ & 24 & 0.4 & $4 \cdot 5$ \\
\hline Avicell| & 0.5 & 4.7 & 0.2 & $2 \cdot 2$ \\
\hline Pectin & 0.2 & I. 9 & - & - \\
\hline Vanilla & $\mathrm{I} \cdot \mathrm{I}$ & 10 & 0.8 & $8 \cdot 9$ \\
\hline Lecithin & $1 \cdot 0$ & 9 & 0.4 & $4 \cdot 5$ \\
\hline $\mathrm{NaCl}$ & $0 \cdot 1$ & $\mathrm{I}$ & $O \cdot I$ & I \\
\hline $\mathrm{K}_{2} \mathrm{HPO}_{4}$ & 0.6 & 5.7 & 0.4 & $4 \cdot 5$ \\
\hline $\mathrm{Ca}_{10}(\mathrm{OH})_{2}\left(\mathrm{PO}_{4}\right)_{6}$ & 0.3 & $2 \cdot 8$ & 0.2 & $2 \cdot 2$ \\
\hline $\mathrm{H}_{2} \mathrm{O}$ & $42 \cdot 4$ & 400 & 60.5 & 675 \\
\hline Total & 100 & 943 & 100 & $\begin{array}{l}115 \\
116\end{array}$ \\
\hline Iron 9 & - & $9+3$ & - & - \\
\hline Vitamins** & - & - & - & - \\
\hline Tomato juice & - & - & - & 100 \\
\hline Maize starch cookies and dessert & - & Variable $† \dagger$ & $\ldots$ & Variable \\
\hline Carbonated beverage & - & Variable & - & Variable \\
\hline $\begin{array}{l}\text { Amount for a 7o kg subject. } \\
\text { Spray-dried, pasteurized whole-eg } \\
\text { Buckeye Rolled Oats, homogeniz } \\
\text { Approximate composition: dextr } \\
\text { kahoe, New York). } \\
\text { Microcrystalline alpha cellulose ( } \\
\text { One tablet supplying } 14 \mathrm{mg} \mathrm{Fe}( \\
\text { Unicap multivitamin capsule (U } \\
\dagger \text { Intake varied among subjects in }\end{array}$ & $\begin{array}{l}\text { er(British } \\
\text { ker Oats } \\
6 \text {; maltos } \\
\text { Corporat } \\
\text { line \& F } \\
\text { ompany } \\
\text { adjust d } \\
\text { or mainte }\end{array}$ & $\begin{array}{l}\text { Marketing } \\
\text { npany, Barrir } \\
4 \% \text { (Burrou } \\
\text { Marcus Hoo } \\
\text { h, Philadelp } \\
\text { lamazoo, Mi } \\
\text { o individual } \\
\text { ce period. }\end{array}$ & $\begin{array}{l}\text { rd, Londo } \\
\text { n, Illinoi } \\
\text { Wellcom } \\
\text { Pennsylva } \\
\text { Pennsyl } \\
\text { ran). } \\
\text { rie needs, }\end{array}$ & d Compa \\
\hline
\end{tabular}


Eight subjects were given the 'protein-free' diet for 7 or ro days (Expt $\mathrm{I}$ ). 'The other three subjects were maintained on this diet for 16 days (Expt 2). Following 3 days on an ad lib. intake, seven of the subjects in Expt $\mathrm{I}$ were given a diet supplying a level of protein intake calculated to cover their minimum $\mathrm{N}$ requirement according to the $\mathrm{FAO} / \mathrm{WHO}(1965)$ factorial approach for $\mathrm{x}_{4}-\mathrm{r} 6$ days. This requirement was estimated from the sum of the urinary and faecal $\mathrm{N}$ losses during the latter part of the 'proteinfree' period, plus a daily allowance of $15 \mathrm{mg} \mathrm{N} / \mathrm{kg}$ for minimal integumental and sweat losses. An allowance of $20 \mathrm{mg} \mathrm{N} / \mathrm{kg}$ body-weight, as proposed in the $\mathrm{FAO} /$ WHO report, was considered too high since these subjects were maintained in an airconditioned environment and in view of the losses found by Mitchell \& Hamilton (1949) and Consolazio, Le Matoush, Nelson, Isaac \& Canham (1966). The composition of the maintenance diet is given in Table 2 . Ninety per cent of the dietary protein at the calculated minimum requirement level was contributed by whole-egg protein with oatmeal and tomato juice each furnishing $5 \%$.

Body cell mass was calculated by determinination of total body ${ }^{40} \mathrm{~K}$ burden, using the M.I.T'. whole body counter. A value of 0.64 count $/ \mathrm{min}$ per $\mathrm{g} \mathrm{K}$ was used as the calibration factor for estimating total body K (Evans, 1964). The relationship between body $\mathrm{K}$ and $\mathrm{N}$ was assumed to be $3 \mathrm{~m}$-equiv. $\mathrm{K} / \mathrm{g} \mathrm{N}$; $\mathrm{Ig} \mathrm{N}$ is equivalent to $25 \mathrm{~g}$ of $\mathrm{BCM}$. No correction was made for the extracellular $\mathrm{K}$ in view of the negligible error from this source (Moore, Olsen, McMurrey, Parker, Ball \& Boyden, 1963).

Basal metabolism was determined by indirect calorimetry at the beginning and end of the experimental period for most subjects, using a Kofranyi-Michaelis respirometer. The $\mathrm{O}_{2}$ and $\mathrm{CO}_{2}$ content of expired gas was analysed by the Scholander microgas technique. The two determinations gave almost identical values, and the mean value is given in the results.

Complete $24 \mathrm{~h}$ collections of urine were made, and faecal samples were pooled. $\mathrm{N}$ determinations were made from urine, faeces and diet, and urinary creatinines were determined daily, all as previously described (Scrimshaw et al. 1966).

Blood for amino acid analysis was taken from the antecubital vein of subjects who had fasted for to h. The blood was analysed for free amino acids (Scrimshaw et al. I966) and for serum total protein and albumin (Annino, I964).

\section{RESULTS}

Table 3 summarizes results obtained for $\mathrm{BCM}$, creatinine excretion and determinations of basal metabolic rate. BCM showed a tendency to decrease in most subjects following the 'protein-free' period. The average decrease of $2 \%$ in BCM was within the $5 \%$ sensitivity of the method. Expressed as a percentage, BCM accounted for $48 \%$ of body-weight, and the calculated mean calorie expenditure of the BCM was $48.5 \mathrm{kcal} / \mathrm{kg}$ BCM day.

Urinary $\mathrm{N}$ excretion for eight subjects given the 'protein-free' diet for a 7 - or 10-day period is shown in Table 4. For 7 -day subjects the value for the last day is given since a steady-state $\mathrm{N}$ excretion was not apparently reached before that time. Because those given the 'protein-free' diet for io days showed a steady-state excre- 
tion after the 6 th or 7 th day, the mean value during the last 3 or 4 days is given. Expressed on a body-weight basis, the mean coefficient of variation (SD $\times$ IOO/mean) of $\mathrm{N}$ excretion per $\mathrm{kg}$ in these eight subjects was $8 . \mathrm{I} \%$. The mean daily value for seven subjects in which an estimation of $\mathrm{BCM}$ was made was $79^{\circ} 4 \mathrm{mg} \mathrm{N} / \mathrm{kg} \mathrm{BCM}$ with a mean coefficient of variation of $5.5 \%$. The relationship between urinary $\mathrm{N}$ excretion and basal metabolism is also shown in Table 4 . The mean value for the eight subjects

Table 3 . Body cell mass $(B C M)$, basal calorie expenditure and urinary creatinine excretion in young men given a 'protein-free' diet for 7-16 days

\begin{tabular}{|c|c|c|c|c|c|c|}
\hline \multirow[b]{2}{*}{ Subject } & \multicolumn{3}{|c|}{$\mathrm{BCM}$} & \multicolumn{2}{|c|}{ Basal calorie expenditure } & \multirow{2}{*}{$\begin{array}{c}\text { Creatinine } \\
\text { excretion } \\
\text { (g/day) }\end{array}$} \\
\hline & $\begin{array}{l}\text { Before* } \\
\text { (kg) }\end{array}$ & $\begin{array}{c}\text { After } \dagger \\
(\mathrm{kg})\end{array}$ & $\begin{array}{c}\% \text { of } \\
\text { body-wt }\end{array}$ & $\mathrm{kcal} / 24 \mathrm{~h}$ & $\begin{array}{c}\mathrm{kcal} / \mathrm{kg} \\
\text { BCM day }\end{array}$ & \\
\hline N.M. & $32 \cdot 9$ & $31 \cdot 9$ & $45 \ddagger$ & $\times 779$ & 54.9 & $I .62 \pm 0.03 \$$ \\
\hline B.R. & $30 \cdot 6$ & $29 \cdot 5$ & 45 & 1580 & 50.8 & $1.64 \pm 0.02$ \\
\hline D.P. & $32 \cdot 0$ & $31 \cdot 6$ & 48 & 1515 & $47 \cdot 6$ & $\mathrm{I} .80 \pm 0.02$ \\
\hline R.W. & $-\|$ & - & - & 1556 & - & $r \cdot 51 \pm 0.19$ \\
\hline M.R. & $37 \cdot 4$ & $37 \cdot 2$ & 49 & 1508 & $40 \cdot 4$ & $I \cdot 96 \pm 0 \cdot 13$ \\
\hline I.J. & 37.4 & $37 \cdot 0$ & 47 & I668 & $44 \cdot 8$ & I. $94 \pm 0 . I_{3}$ \\
\hline J.S. & $32 \cdot 1$ & $32 \cdot 5$ & 48 & 1605 & 49.7 & $1.54 \pm 0.23$ \\
\hline P.S. & $36 \cdot 9$ & $36 \cdot 2$ & 42 & 1876 & $5 \pi^{\circ} \cdot 3$ & $\mathrm{I} .87 \pm 0.03$ \\
\hline G.C. & $33 \cdot 9$ & 33.9 & 53 & - & - & $1.72 \pm 0.03$ \\
\hline W.S. & $31 \cdot 5$ & $29 \cdot 8$ & 47 & - & - & $\mathrm{I} \cdot 6 \mathrm{x} \pm 0.33$ \\
\hline J.G. & 36.0 & $36 \cdot 4$ & 53 & - & $\ldots$ & $1.71 \pm 0.06$ \\
\hline Mean & $34 \cdot 1$ & $33 \cdot 6$ & 48 & 1636 & $48 \cdot 5$ & $I \cdot 72$ \\
\hline
\end{tabular}

* At beginning of 'protein-free' period.

+ On last day of 'protein-free' period.

$\ddagger$ Mean values for BCM used.

$\S$ Mean values and standard deviations for last 4 days of 'protein-free' period.

II Not measured.

Table 4. Expt I. Endogenous urinary and faecal $N$ excretion by young men given a 'protein-free' diet for 7-10 days

\begin{tabular}{|c|c|c|c|c|c|c|c|c|c|}
\hline \multirow[b]{2}{*}{ Subject } & \multirow[b]{2}{*}{$\begin{array}{l}\text { Days on } \\
\text { "protein- } \\
\text { free" } \\
\text { diet }\end{array}$} & \multicolumn{4}{|c|}{ Urinary $N /$ day } & \multicolumn{4}{|c|}{ Faecal N/day } \\
\hline & & $\mathbf{g}$ & $\begin{array}{c}\mathrm{mg} / \mathrm{kg} \\
\text { body-wt }\end{array}$ & $\begin{array}{l}\mathrm{mg} / \mathrm{kg} \\
\mathrm{BCM}^{*}\end{array}$ & $\begin{array}{c}\mathrm{mgl} \\
\text { basal } \\
\text { kcal }\end{array}$ & $\mathbf{g}$ & $\begin{array}{c}\mathrm{mg} / \mathrm{kg} \\
\text { body-wt }\end{array}$ & $\begin{array}{l}\mathrm{mg} / \mathrm{kg} \\
\mathrm{BCM}^{*}\end{array}$ & $\begin{array}{c}\% \text { of } \\
\text { total } N \\
\text { excretion }\end{array}$ \\
\hline N.M. & 7 & $2 \cdot 70 \dagger$ & $37 \cdot I$ & $84 \cdot 6$ & $r \cdot 5$ & $0.63 \ddagger$ & $8 \cdot 7$ & 19.7 & I 8.9 \\
\hline B.R. & 7 & $2 \cdot 33$ & $34 \cdot 6$ & $79^{\circ} \circ$ & $1 \cdot 5$ & 0.68 & 10.1 & $23 \cdot I$ & $22 \cdot 6$ \\
\hline D.P. & 7 & $2 \cdot 32$ & $34 \cdot 6$ & 73.4 & $x \cdot 5$ & 0.62 & $9 \cdot 3$ & 19.6 & $2 r \cdot I$ \\
\hline R.W. & roई & $2 \cdot 70$ & $38 \cdot 6$ & - & $r \cdot 7$ & 0.56 & $8 \cdot 0$ & - & $17 \cdot 2$ \\
\hline M.R. & 10 & $2 \cdot 94$ & $38 \cdot 8$ & $79^{\circ} \circ$ & $1 \cdot 9$ & 0.80 & $10 \cdot 6$ & $2 I \cdot 5$ & $21 \cdot 4$ \\
\hline I.J. & IO & 3.05 & $38 \cdot \mathbf{I}$ & $82 \cdot 4$ & $r \cdot 8$ & 0.73 & $9 \cdot 1$ & $19 \cdot 7$ & $19 \cdot 3$ \\
\hline J.S. & 10 & $2 \cdot 70$ & $40 \cdot 0$ & $83 \cdot I$ & $r \cdot 7$ & 0.60 & 8.9 & $18 \cdot 5$ & $18 \cdot 1$ \\
\hline P.S. & 10 & 2.69 & $3 \mathrm{I} \cdot 0$ & $74 \cdot I$ & $I \cdot 4$ & 0.63 & $7 \cdot 3$ & $17 \cdot 4$ & $19^{\circ} 0$ \\
\hline Mean & - & $2 \cdot 68$ & $36 \cdot 6$ & $79 \cdot 4$ & $x \cdot 6$ & 0.66 & $9 \cdot 0$ & I9.9 & $19 \cdot 7$ \\
\hline SD & - & - & 2.98 & $4 \cdot 36$ & 0.18 & - & I.06 & $I \cdot 88$ & $x \cdot 83$ \\
\hline
\end{tabular}

* Body cell mass.

$\uparrow$ Value for 7 th day of 'protein-free' period.

I Pooled faecal sample for last 3 or 4 days of 'protein-free' period.

$\S$ Urinary values for subjects given the diet for ro days are mean values for days $7-10$. 
was found to be $1 \cdot 6 \mathrm{mg} \mathrm{N} /$ basal kcal, with a range of from $\mathrm{I} \cdot 4$ to $\mathrm{r} \cdot 9$. The overall coefficient of variation was approximately II \%, which is slightly higher than the variability found for $\mathrm{N}$ excretion when expressed on the basis of body-weight.

Faecal $\mathrm{N}$ excretion for these subjects is summarized in Table 4. The mean daily rate of metabolic faecal $\mathrm{N}$ excretion was found to be $9.0 \mathrm{mg} / \mathrm{kg}$ body-weight with a coefficient of variation of $1 \mathrm{I} \cdot 8 \%$. Faecal $\mathrm{N}$ appeared to account for $19.7 \%$ of the total daily urinary plus faecal loss in these eight subjects during the last few days of the 'protein-free' period.

Table 5. Expt 2. Mean urinary and faecal $N$ excretion by young men given a 'protein-free' diet for 16 days

\begin{tabular}{|c|c|c|c|c|c|c|c|c|}
\hline \multirow[b]{3}{*}{ Subject } & \multirow{3}{*}{$\begin{array}{c}\text { Days of } \\
\text { 'protein- } \\
\text { free' } \\
\text { diet }\end{array}$} & \multirow{2}{*}{\multicolumn{3}{|c|}{ Urinary $\mathrm{N} /$ day }} & \multicolumn{4}{|c|}{ Faecal N/day } \\
\hline & & & & & \multirow[b]{2}{*}{$\mathrm{g}$} & \multirow[b]{2}{*}{$\begin{array}{c}\mathrm{mg} / \mathrm{kg} \\
\text { body-wt }\end{array}$} & \multirow[b]{2}{*}{$\begin{array}{l}\mathrm{mg} / \mathrm{kg} \\
\mathrm{BCM}\end{array}$} & \multirow{2}{*}{$\begin{array}{c}\% \text { of } \\
\text { total } \mathrm{N} \\
\text { excretion }\end{array}$} \\
\hline & & $\mathrm{g}$ & $\underset{\text { body-wt }}{\mathrm{mg} / \mathrm{kg}}$ & $\begin{array}{l}\mathrm{mg} / \mathrm{kg} \\
\mathrm{BCM}^{*}\end{array}$ & & & & \\
\hline \multirow[t]{3}{*}{ G.C. } & $6-10$ & $2 \cdot 47$ & $3^{8 \cdot 3}$ & $72 \cdot 9$ & 0.64 & $9 \cdot 9$ & 18.9 & $20 \cdot 6$ \\
\hline & $x x-13$ & $2 \cdot 26$ & $35^{\circ} \circ$ & $66 \cdot 7$ & 0.85 & 13.2 & 25.1 & $27 \cdot 3$ \\
\hline & $14-16$ & $2 \cdot 21$ & $34 \cdot 3$ & $65 \cdot 2$ & 0.89 & $\mathrm{r} 3 \cdot 8$ & $26 \cdot 3$ & $28 \cdot 7$ \\
\hline \multirow[t]{3}{*}{ W.S. } & 6-10 & $2 \cdot 25$ & 34.7 & $75 \cdot 5$ & 0.51 & $7 \cdot 9$ & $17 \cdot 1$ & $18 \cdot 5$ \\
\hline & I I-I3 & $2 \cdot 12$ & $32 \cdot 7$ & $7 I \cdot I$ & 0.48 & $7 \% 4$ & $I 6 \cdot I$ & 18.5 \\
\hline & $14-16$ & $2 \cdot 82$ & 43.5 & 94.6 & 0.65 & 10.0 & $21 \cdot 8$ & 18.7 \\
\hline \multirow[t]{3}{*}{ J.G. } & $6-10$ & 2.42 & $35 \cdot 7$ & $66 \cdot 5$ & 0.56 & $8 \cdot 3$ & $15 \cdot 4$ & $18 \cdot 8$ \\
\hline & $I_{1}-x_{3}$ & $2 \cdot 4 I$ & $35 \cdot 6$ & $66 \cdot 2$ & 0.39 & $5 \cdot 8$ & 10.7 & 13.9 \\
\hline & $14-16$ & $2 \cdot 32$ & $34 \cdot 3$ & 63.7 & 0.89 & 13.1 & $24 \cdot 5$ & 27.7 \\
\hline \multirow[t]{3}{*}{ Mean } & 6-10 & $2 \cdot 38$ & $36 \cdot 2$ & $71 \cdot 6$ & 0.57 & 8.7 & $17 \cdot 1$ & $19 \cdot 3$ \\
\hline & I I-I3 & $2 \cdot 26$ & $34 \%$ & $68 \cdot 0$ & 0.57 & $8 \cdot 8$ & $17 \cdot 3$ & 19.9 \\
\hline & $14-16$ & $2-45$ & $37 \cdot 4$ & 74.5 & 0.81 & I $2 \cdot 3$ & $24 \cdot 2$ & 25.0 \\
\hline
\end{tabular}

Results for the three subjects given a 'protein-free' diet for 16 days in Expt 2 are summarized in Table 5. During days 6-IO, II-I3, and $14-16$, the mean urinary excretion values for the three subjects were $36 \cdot 2,34^{\circ} 4$, and $37^{\circ} 4 \mathrm{mg} \mathrm{N} / \mathrm{kg}$ body-weight per day, respectively, and these values compare well with those shown in Table 4 for subjects in Expt $\mathrm{r}$. Urinary $\mathrm{N}$ excretion on a BCM basis appeared to be slightly lower for these three subjects than for the seven subjects studied in Expt I. The mean values of $7 \mathrm{I} \cdot 6,68 \cdot 0$ and $74 \cdot 5 \mathrm{mg} / \mathrm{kg}$ BCM during days $6-10, \mathrm{II}_{-1} \mathrm{I}_{3}$, and $\mathrm{I}_{4}-\mathrm{I} 6$, respectively, compare with $79^{\circ} 4 \mathrm{mg} / \mathrm{kg} \mathrm{BCM}$ for the seven subjects studied during a shorter period of 'protein-free' diet.

Faecal $\mathrm{N}$ excretion in Expt 2 is summarized in Table 5. The results are in general agreement with those obtained in Expt $\mathrm{I}$ and shown in Table 4.

Following the 'protein-free' period, seven subjects were allowed 3 days on an $a d$ lib. diet and then given protein at a level calculated to be close to their minimum $\mathrm{N}$ requirements for $14-16$ days. Comparison of $\mathrm{N}$ excretion in subjects given a proteinmaintenance diet with excretion in the same subjects given a 'protein-free' diet showed that the former level was significantly higher in all subjects following achievement of a relatively steady rate of $\mathrm{N}$ excretion. The mean rate of urinary $\mathrm{N}$ excretion was $59^{\circ} \mathrm{Img} / \mathrm{kg}$ day for the protein diet compared with $37.4 \mathrm{mg} / \mathrm{kg}$ day for the 
'protein-free' diet, a difference of $2 \mathrm{I} \cdot 7 \pm \mathrm{I} \cdot 97$ (6 df). Mean faecal N excretion did not significantly increase after giving $\mathrm{N}$ at the calculated level of each subject's minimum requirement. The mean value was $9.7 \mathrm{mg} / \mathrm{kg}$ for the protein diet and $9.2 \mathrm{mg} / \mathrm{kg}$ for the 'protein-free' diet, a difference of $0.5 \pm 0.6(6 \mathrm{df})$.

Table 6. Mean values for serum total protein, albumin and plasma free amino acids and mean differences with their standard errors after giving two groups of young men a 'protein-free' diet for 7-16 days

\begin{tabular}{|c|c|c|c|c|}
\hline & \multicolumn{2}{|c|}{ Group I $†$} & \multicolumn{2}{|c|}{ Group $2 t$} \\
\hline & Day o & $\begin{array}{l}\text { Difference at } \\
7 \text { or 1o days }\end{array}$ & Day o & $\begin{array}{l}\text { Difference at } \\
\text { I6 days }\end{array}$ \\
\hline Serum protein $(\mathrm{g} / \mathrm{r} 00 \mathrm{ml})$ & $7 \cdot 1$ & $-0.3 \pm 0.08 * *$ & $6 \cdot 8$ & -0.2 \\
\hline Serum albumin $(\mathrm{g} / \mathrm{1} 00 \mathrm{ml})$ & $4 \cdot 3$ & $-0.1 \pm 0.04^{*}$ & $4 \cdot 0$ & +0.4 \\
\hline \multicolumn{5}{|c|}{ Essential amino acid $(\mu$ moles/1.) } \\
\hline Threonine & 233 & $-16 \pm 12$ & 212 & -57 \\
\hline Valine & 260 & $-79 \pm 9 * *$ & 217 & -57 \\
\hline Cystine (half) & 71 & $-7 \pm 7$ & 66 & 0 \\
\hline Isoleucine & $9 \mathbf{I}$ & $-17 \pm 4^{* *}$ & 80 & -15 \\
\hline Leucine & $\mathbf{1 6 6}$ & $-26 \pm 5 * *$ & 139 & -23 \\
\hline Tyrosine & 75 & $-10 \pm 3 * *$ & 60 & -6 \\
\hline Phenylalanine & 73 & $-6 \pm 3$ & 62 & -2 \\
\hline Lysine & 239 & $-3 x \pm 8 * *$ & 209 & -40 \\
\hline Total $(E)$ & I 208 & $-192 \pm 35^{* *}$ & I045 & -200 \\
\hline \multicolumn{5}{|c|}{ Non-essential amino acid ( $\mu$ moles $/ 1$.$) :$} \\
\hline Aspartic & $4 I$ & $+18 \pm 6^{*}$ & 41 & \\
\hline Serine and glutamine & 199 & $+9 \pm 46$ & 194 & -6 \\
\hline Glutamic & 307 & $+102 \pm 19 *$ & 228 & +36 \\
\hline Citrulline & 40 & $+5 \pm 3$ & $4 \mathrm{I}$ & -2 \\
\hline Glycine & 319 & $+96 \pm 22^{* *}$ & 280 & +86 \\
\hline Alanine & 447 & $+329 \pm 35^{* *}$ & 315 & +397 \\
\hline$\alpha$-Aminobutyric & 27 & $-I_{5} \pm 2^{* *}$ & 35 & -22 \\
\hline Ornithine & 76 & $-5 \pm 4$ & 72 & -5 \\
\hline Histidine & I05 & $-12 \pm 5^{*}$ & 98 & -7 \\
\hline Arginine & I 16 & $-6 \pm 9$ & 98 & +9 \\
\hline Total $(N)$ & 1682 & $+521 \pm 53^{* *}$ & 1402 & +480 \\
\hline Ratio $(E: N)$ & 0.72 & $-0.28 \pm 0.03^{* *}$ & 0.75 & -0.29 \\
\hline
\end{tabular}

Positive sign indicates increase; negative sign indicates decrease.

*, ** Difference significant by paired $t$ test at 0.05 and 0.01 levels, respectively.

+ Group I: seven subjects from Expt $I$ and three subjects from Expt 2.

I Group 2: mean values from three subjects in Expt 2.

Methionine peak was too low for accurate determination and was omitted from the results. Tryptophan was not determined.

As shown in Table 6 , the concentrations of serum albumin and total protein were slightly, though significantly, decreased by 'protein-free' intake for 7-ro days. The mean plasma albumin level showed an increase on the $\mathrm{I} 6$ th day in the three subjects studied during Expt 2. The basal (day o) amino acid values refer to analysis of blood samples taken before the 'protein-free' regimen while all subjects (group I) were receiving a diet containing $0 \cdot 8-\mathrm{r} \cdot \circ \mathrm{g}$ protein $/ \mathrm{kg}$ day. The concentrations of valine, isoleucine, leucine, tyrosine and lysine were significantly reduced $(P<0.01) 7$ days after the 'protein-free' diet was started. Similar results were obtained for three subjects (group 2) after 16 days of giving the 'protein-free' diet. Threonine appeared to 
show a greater decrease after $\mathrm{I} 6$ days than during the first ro days of the experiment. The total essential amino acids decreased significantly $(P<0.01)$ after giving the 'protein-free' diet for 7 or ro days.

The plasma non-essential amino acids responded variably to a protein-free regimen. Aspartic acid, glutamic acid, glycine and alanine increased significantly after 7 or to days. $\alpha$-Aminobutyric acid decreased to some $30-50 \%$ of the control values in these two experiments. The total non-essential amino acids increased $(P<0.01)$, and the ratio of essential to non-essential amino acids (ratio $E: N)$ decreased $(P<0.0 \mathrm{I})$ significantly after 7 -Io days on the 'protein-free' diet but showed no further change by day I6. The results obtained with three subjects after 16 days of giving the 'proteinfree' diet were similar to those obtained after ro days on the 'protein-free' diet.

\section{DISCUSSION}

\section{Endogenous urinary $N$}

On the basis of results for five animal species (mice, rats, guinea-pigs, rabbits, pigs), Smuts (1935) proposed a value of $\mathbf{2} \mathrm{mg} \mathrm{N} / \mathrm{basal} \mathrm{kcal}$ for the relationship between basal metabolic rate and endogenous urinary $\mathrm{N}$. 'This value was used by the recent FAO/ WHO Expert Group on Protein Requirements to estimate the protein requirement of man by the factorial approach (FAO/WHO, 1965). However, for the eight subjects studied in the present experiments, the relationship between urinary $\mathrm{N}$ and metabolic rate was found to be $1 \cdot 6 \pm 0.2 \mathrm{mg} \mathrm{N} / \mathrm{basal} \mathrm{kcal}$, a value substantially lower than that used by the FAO/WHO Expert Group. On the basis of our limited results, endogenous urinary $\mathrm{N}$ excretion would be less than $2 \mathrm{mg} \mathrm{N} /$ basal kcal in approximately $98 \%$ of the adult population.

Our results are similar to the value of $\mathrm{r} \cdot 48 \mathrm{mg} \mathrm{N} /$ basal kcal found by Murlin $e$ al . (1946a) for five young men and to the value of $\mathrm{I} \cdot 7 \mathrm{mg} \mathrm{N} / \mathrm{basal} \mathrm{kcal}$ found by Smith (1926) for a healthy young man after 23 days of eating a low-protein diet.

Recently, Gopalan \& Narasinga Rao (1966), in their studies of endogenous N excretion in four undernourished subjects, found a mean value of $\mathrm{x} \cdot 4 \mathrm{mg} / \mathrm{basal} \mathrm{kcal}$. Fomon, DeMaeyer \& Owen ( 1965$)$ calculated, for adult men, a value of $\mathrm{I} \cdot 2 \mathrm{mg} / \mathrm{basal}$ kcal from the $\mathrm{N}$ balance results of Hawley, Murlin, Nasset \& Szymanski (1948), and a value of $1.5 \mathrm{mg} / \mathrm{basal} \mathrm{kcal}$ from the results of Mueller \& Cox (1947). Using their own $\mathrm{N}$ balance results, Fomon et al. (1965) arrived at a value of only $0.6-0.8 \mathrm{mg} \mathrm{N} /$ basal $\mathrm{kcal}$ for infants aged $4^{-6}$ months and $0.9^{-1} \cdot 4 \mathrm{mg} \mathrm{N} /$ basal kcal for $3^{-}$to 4 -year-old children.

Judging from the results of Fomon et al. (1965) for children compared with the values for adults, urinary $\mathrm{N}$ excretion per kcal of basal metabolism apparently increases with age. Similar results have been recorded for rats by Ashworth (1935) and Ashworth \& Cowgill (1938), who found that $\mathrm{N}$ excretion for weanlings was $\mathrm{I} \cdot \circ \mathrm{mg}$ / basal kcal compared with $1 \cdot 5 \mathrm{mg} /$ basal kcal for adults.

Urinary $\mathrm{N}$ excretion appeared to reach a relatively constant level after the 6th or 7 th day of a 'protein-free' diet, and this level was maintained for the remaining 4 or Io days of study. These results are in agreement with those obtained for both children 
and adult subjects. As would be expected, the previous level of protein intake influences the time at which a relatively constant rate of excretion is achieved. Gopalan \& Narasinga Rao (I966) found that urinary $N$ excretion reached a steady value within 2-3 days in undernourished adults.

The results obtained for man appear to differ from those reported for experimental animals. Allison \& Wannemacher ( 1965$)$ showed that urinary $\mathrm{N}$ excretion became relatively constant in rats and dogs only after a loss of about $25 \%$ of body $\mathrm{N}$. In contrast, a constant rate of excretion in an adult man is attained after approximately $5 \%$ of body $\mathrm{N}$ has been lost (Munro, 1964 ). There may be, therefore, species differences in the metabolic response to a 'protein-free' diet.

The additional $\mathrm{N}$ above the level of urinary endogenous excretion which is lost during the first few days on a 'protein-free' diet has been taken to represent labile body protein. Martin \& Robison (1922) developed a procedure for estimating an empirical rate constant $(k)$ related to rate of urinary $\mathrm{N}$ excretion when subjects are given a 'protein-free' diet. For two adult males, they obtained a mean value for $k$ of 0.35 . Using their equation, Munro (1964) calculated an average value of 0.22 for rats and $0 \cdot 18$ for dogs. Although these values are highly tentative, they tend to support our view that man responds differently from the rat and dog to a 'protein-free' diet, if judged by the rate at which a relatively constant level of urinary $\mathrm{N}$ excretion is attained.

Basal urinary $\mathrm{N}$ excretion was found to be $36 \cdot 6 \pm 3 \cdot \circ \mathrm{mg} / \mathrm{kg}$ body-weight per day in the eight subjects studicd for a 7 - or Io-day 'protein-free' period; similar values were obtained in three additional subjects during days $6-\mathrm{I} 6$ of a 16 -day 'protein-free' period. These values are in reasonable agreement with those summarized by Fomon et al. (1965). The standard deviation of $\mathrm{N}$ excretion among these eleven subjects was about $10 \%$ of the mean. Although this is substantially lower than the range of variation in the requirement for individual amino acids referred to earlier (Rose, 1957; Leverton et al. 1956; Swendseid \& Dunn, 1956), it is identical with the variation in endogenous $\mathrm{N}$ loss assumed by the $\mathrm{FAO} /$ WHO Expert Group on Protein Requirements (FAO/WHO, I965). In view of these findings, endogenous $\mathrm{N}$ loss does not reflect to any great extent the much greater variability in individual amino acid requirements, and other factors, either physiological or experimental, must play a more significant part in this respect. It should be emphasized, however, that these values were obtained from subjects studied within the sheltered environment of a hospital metabolic ward. It is possible that endogenous $\mathrm{N}$ excretion would show greater variability among subjects studied under the usual conditions of daily living.

\section{Faecal $N$ loss}

Faecal $\mathrm{N}$ loss on a 'protein-free' diet has been shown to account for approximately $20 \%$ of the combined urinary and faecal $\mathrm{N}$ loss, with mean daily values of $9.0 \mathrm{mg} / \mathrm{kg}$ body-weight in Expt $\mathrm{I}$ and $5.8-13.8 \mathrm{mg} / \mathrm{kg}$ body-weight during days 6-16 in Expt 2. Hawley et al. (1948) determined that faecal N loss accounted daily for $28 \%$ of the total $\mathrm{N}$ loss and amounted to I I mg/kg body-weight. Mueller \& Cox (1947) found that it amounted to $13 \mathrm{mg} / \mathrm{kg}$ and $22 \%$ of the total $\mathrm{N}$ loss during days $4^{-6}$ of a 'protein- 
free' diet; these results are in good agreement with ours. In children, metabolic faecal $\mathrm{N}$ loss accounts for approximately one-third of the total excretion (Fomon et al. 1965). The values found in the present study and those of the above workers are substantially lower than the $20 \mathrm{mg}$ faecal N/kg body-weight allowed for by the FAO/WHO Expert Group $(\mathrm{FAO} / \mathrm{WHO}, 1965)$ in assessing the protein requirements of man.

When subjects were given a level of $\mathrm{N}$ intake calculated to approximate to their minimum requirement, including $15 \mathrm{mg} \mathrm{N} / \mathrm{kg}$ body-weight per day for cutaneous loss, urinary $\mathrm{N}$ excretion reached a constant level which averaged $58 \%$ higher than that observed during the 'protein-free' period. Faecal N losses were not significantly higher than those observed during the 'protein-free' period.

In their studies of the biological value of egg protein, Murlin et al. (1946a) used a level of protein intake calculated by adding the faecal and urinary $\mathrm{N}$ losses measured 4 days after their subjects had been on a diet supplying less than $0.4 \mathrm{~g} \mathrm{~N} /$ day. These workers did not observe as great an increase in urinary $\mathrm{N}$ excretion during the period in which the minimum requirement of protein was given as was found in the present study. As a result, their calculated biological value for egg protein given at requirement levels was 88.6 (Murlin, Edwards, Hawley \& Clark, $1946 b$ ) in contrast to a value of 65 found in our study. The most probable explanation is that the egg powder used in our study was damaged in processing or storage and did not have the expected biological value. Determination, by the method of Miller \& Bender (1955), of the net protein utilization (NPU) for rats maintained in air-conditioned quarters at $24^{\circ}$ revealed a value of $79 \pm 2$ for the dried whole-egg powder used in these experiments compared with $63 \pm 2$ for casein and values of $93-97$ reported by Venkat Rao, Daniel, Joseph, Sankaran \& Swaminathan (1964) for whole-egg powder. The present NPU results would preclude the use of these values for estimating obligatory $\mathrm{N}$ loss when young men are given a level of whole-egg protein calculated to meet maintenance needs.

Grande (I96I) has estimated the mean calorie expenditure per $\mathrm{kg}$ of 'active tissue' to be $\mathrm{I} \cdot 6 \mathrm{kcal} / \mathrm{kg}$ 'cells' $\mathrm{h}$, or $38.4 \mathrm{kcal} / \mathrm{kg}$ 'cells' day. This value may be compared with those shown in Table 3 which vary between 40.4 and 54.9 , with a mean value of $48 \cdot 5 \mathrm{kcal} / \mathrm{kg} \mathrm{BCM}$ day. However, Moore et al. $(1963)$ suggest a range of $64 \cdot 8-86 \cdot 4$ $\mathrm{kcal} / \mathrm{kg} \mathrm{BCM}$ day, substantially higher than the values found in the present experiments or in those of Grande (196r) and Grande, Anderson \& Keys (1958). BCM was found to be approximately $48 \%$ of body-weight in the present experiments, compared with the range of $35-45 \%$ calculated by Moore et al. (1963) from total body exchangeable $\mathrm{K}$, determined with ${ }^{42} \mathrm{~K}$.

\section{Plasma amino acids}

Of the free essential amino acids in the plasma, valine, isoleucine, leucine, tyrosine and lysine decreased significantly after 7 or 10 days of giving a 'protein-free' diet. The responsiveness of plasma valine in older men given a low-protein diet supplying $3.5 \mathrm{~g}$ $\mathrm{N} /$ day has recently been discussed by Swendseid $e t$ al. (I966). The branched-chain amino acids are reduced in children suffering from kwashiorkor and marasmus (Arroyave, Wilson, de Funes \& Béhar, 1962; Holt \& Snyderman, 1965). The present 
study shows that the levels of these amino acids in the plasma respond rapidly to acute protein deprivation in young adults.

The plasma $E: N$ ratio decreased after Io days of 'protein-free' intake, but did not appear to decrease further by day 16 in Expt 2. Swendseid et al. (1966) have suggested that a low $E: N$ ratio might be taken as an indicator of some degree of protein depletion. Though the present studies and those of Swendseid et al. (1966) show that the ratio changes with adequacy of protein intake in healthy aduits, the reliability of the ratio as an index of protein status requires further evaluation in view of the small, though statistically significant, change of serum albumin concentration during the 7 or Io days after giving a 'protein-free' diet in the present experiments. It is relevant to record that Whitehead \& Dean (1964) and McLaren, Kamel \& Ayyoub (1965) have failed to demonstrate a correlation between the imbalance of essential to the nonessential amino acids in plasma and the clinical degree of protein malnutrition.

The authors acknowledge the kind aid of Dr Kolenkow of the Department of Physics, M.I.T., for arranging the use of the whole body counter and of Dr J. B. Das for his supervision of the subjects and basal metabolic rate measurements. We are indebted to M. L. Piché, Dr H. Zyas Byzan, F. Larin, and C. Squires for their technical assistance. The co-operation of the subjects who participated in these experiments is greatly appreciated.

This study was supported in part by USA National Institutes of Health, grant no. AM 06274 and utilized facilities of the M.I.T. Clinical Research Center financed by grant no. GM $7073^{8}$.

\section{REFERENCES}

Allison, J. B. \& Wannemacher, R. W. Jr (1965). Am. F. clin. Nutr. 16, 445.

Annino, J. S. (1964). Clinical Chemistry, 3rd ed. Boston: Little, Brown and Co.

Arroyave, G., Wilson, D., de Funes, C. \& Béhar, M. (I962). Am. F. clin. Nutr. Ir, 5 I7.

Ashworth, U. S. (1935). Res. Bull. Mo. agric. Exp. Stn no. 233, p. 20.

Ashworth, U. S. \& Cowgill, G. R. (1938). F. Nutr. 15, 73.

Bricker, M. L. \& Smith, J. M. (195I). F. Nutr. 44, 553.

Clark, H. E., Kenney, M. A., Goodwin, A. F., Goyal, K. \& Mertz, E. F. (Ig63). F. Nutr. 8x, 233.

Clark, H. E., Myers, P., Goyal, K. \& Rinehart, J. (1966). Am. F. clin. Nutr. 18, 91.

Consolazio, C. F., Le Matoush, R. O., Nelson, R. A., Isaac, G. J. \& Canham, J. E. (Ig66). Am. F. clin. Nutr. I8, 443 .

Deuel, H. J. Jr, Sandiford, I., Sandiford, K. \& Boothby, W. M. (I928). F. biol. Chem. 76, 391.

Evans, R. D. (1964). Annual Progress Report, M.I.T.-952-1 Contract AT 30-D-952, U.S. Atomic Energy Commission, Division of Biology and Medicine, May r 964.

FAO/WHO (1965). Tech. Rep. Ser. Wld Hith Org. no. 3 or.

Fomon, S. J., DeMaeyer, E. M. \& Owen, G. M. (1965). F. Nutr. 85, 235.

Gopalan, C. \& Narasinga Rao, B. S. (1 g66). F. Nutr. 90, 2 13.

Grande, F. (I96I). In Techniques for Measuring Body Composition, p. x72. [T. Brozek and A. Herschel, editors.] Washington, D.C.: National Academy of Sciences and National Research Council.

Grande, F., Anderson, J. T. \& Keys, A. (1958). F. appl. Physiol. 12, 230.

Harper, A. E. (1 964). In Mammalian Protein Metabolism. Vol. 2, p. 87. [H. N. Munro and J. B. Allison, editors.] New York: Academic Press Inc.

Hawley, E. E., Murlin, J. R., Nasset, E. S. \& Szymanski, T. A. (1948). F. Nutr. 36, 153.

Holt, L. E. \& Snyderman, S. E. (Ig65). Nutr. Abstr. Rev. 35, x.

Huang, P. C., Young, V. R., Cholakos, B. \& Scrimshaw, N. S. (1966). F. Nutr. 90, 4 I6.

Kies, C. V., Shortridge, L. \& Reynolds, M. S. (1965). F. Nutr. 85, 260.

Leverton, R. M., Ellison, J., Johnson, N., Pazur, J., Schmidt, F. \& Geschwender, D. (1956). F. Nutr. 58,355 .

McLaren, D. S., Kamel, W. W. \& Ayyoub, N. (1965). Am. F. clin. Nutr. 17, 152. 
Martin, C. J. \& Robison, R. (1922). Biochem. \%. 16, 407.

Miller, D. S. \& Bender, A. E. (1955). Br. F. Nutr. 9, 382.

Mitchell, H. H. \& Hamilton, T. S. (I949). F. biol. Chem. 178, 345.

Moore, F. D., Olsen, K. O., McMurrey, J. D., Parker, H. V,, Ball, M. R. \& Boyden, C. M. (I963). The Body Cell Mass and Its Supporting Environment. Philadelphia: Saunders.

Mueller, A. J. \& Cox, W. M. Jr (1947). F. Nutr. 34, 285.

Munro, H. N. (1964). In Mammalian Protein Metabolism. Vol. I, p. 38 . [H. N. Munro and J. B. Allison, editors.] New York: Academic Press Inc.

Murlin, J. R., Edwards, L. E., Hawley, E. E. \& Clark, L. C. (r946a). F. Nutr. 3r, 533.

Murlin, J. R., Edwards, L. E., Hawley, E. E. \& Clark, L. C. (1946b). F. Nutr. 31, 555.

Rose, W. C. (1957). Nutr. Abstr. Rev. 27, 631.

Scrimshaw, N. S. (1962-3). Harvey Lect. 58, 181 .

Scrimshaw, N. S., Bressani, R., Béhar, M. \& Viteri, F. (1958). F. Nutr. 66, 485.

Scrimshaw, N. S., Young, V. R., Schwartz, R., Piché, M. L. \& Das, J. B. (I 966). J. Nutr. 89, 9.

Smith, M. (1926). F. biol. Chem. 68, 15 .

Smuts, D. B. (1935). F. Nutr. 9, 403 .

Swendseid, M. E. \& Dunn, M. S. (1956). F. Nutr. 58, 507.

Swendseid, M. E., Tuttle, S. G., Figueroa, W. S., Mulcare, D., Clark, A. J. \& Massey, F. J. (1966). F. Nutr. 88, 239 .

Tuttle, S. G., Swendseid, M. E., Mulcare, D., Griffith, W. H. \& Bassett, S. H. (1959). Metabolism 8, 6r.

Venkat Rao, S., Daniel, V. A., Joseph, A. A., Sankaran, A. N. \& Swaminathan, M. (1964). f. Nutr. Dietet. I, 103 .

Watt, B. K. \& Merril, A. L. (1963). Composition of Foods. Agric. Handbook no. 8. Washington, D.C.: United States Drug Administration.

Whitehead, R. G. \& Dean, R. F. A. (1964). Am. F. clin. Nutr. 14, 320. 